\title{
TAX MANEUVER: ECONOMIC GROWTH ACCELERATION TO THE DETRIMENT OF BUDGET CONSOLIDATION ${ }^{1}$
}

\author{
G.Idrisov, A.Kaukin
}

The taxation reform in the oil and oil-refining industries in 2014 - the 'tax maneuver' - was designed to boost the performance of domestic oil refineries. In late 2015, the planned reduction of export duty was suspended in order to keep unchanged the volume of tax-generated revenues under the new terms of trade. However, our calculations demonstrate that full implementation of the tax maneuver will not only result in the accomplishment of that task, but prevent growth of wholesale and retail prices of petroleum products, as well as conduce to increasing the value added created by Russia's oilrefining sector. ${ }^{1}$

The measures that envisage a gradual reduction of the export duty on oil alongside raise of mineral resources extraction tax (MRET), which were elaborated in 2014 and then consolidated in legislation (the so-called 'tax maneuver') ${ }^{2}$, are designed to eliminate the non-productive subsidizing of the national economy by keeping domestic oil prices at a low level ${ }^{3}$. The mechanism behind that subsidizing builds on the assumption that the use of cheap oil ${ }^{4}$ produces cheap petroleum products, which will create competitive advantages for domestic companies and bring down their costs. However, in actual practice such a mechanism does not work, because nearly the entire amount

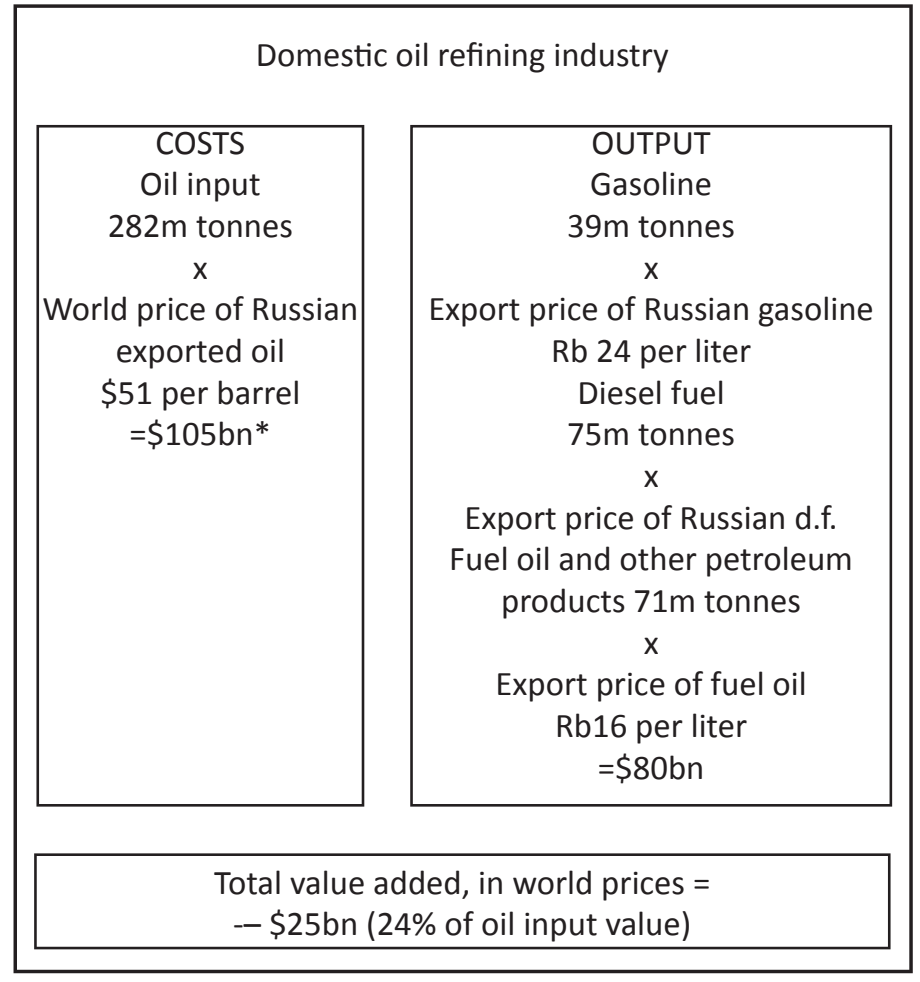

* the industry's estimated costs are shown at the bottom, less wages and 'other' costs.

Sources: Rosstat; FTS; own calculations.

Fig. 1. Russia's oil-refining value added, in 2015 prices

1 This paper was originally published in Online Monitoring of Russia's Economic Outlook No.9(27).

2 The tax maneuver parameters for 2017: the basic rate of MRET is to be raised from Rb 857 to $\mathrm{Rb} 919$ per tonne; the coefficient applied to price of Urals in the EX (export duty) formula is to be reduced from 0.42 to 0.30 ; the coefficient applied to the EX on oil in the formula for EX on gasoline is to be reduced from 0.48 to 0.3 , and that on fuel oil - increased from 0.76 to 1.0; the excise on gasoline is to be reduced from $\mathrm{Rb} 10,130$ to $\mathrm{Rb} 7,430$ per tonne.

3 For more details on the reasons for implementing the tax maneuver, see Idrisov G.I., Sinelnikov-Murylev S.G. Oil Export Duty: Cancel or Preserve. Neft Rossii, No 12, December, 72-77; Idrisov G.I., Sinelnikov-Murylev S.G. Modernization or Conservation: the Role of Export Duties on Oil and Oil Products. Economic Policy, 2012, No.3, pp. 5-19.

4 Due to the export duty levied on oil, Russia's domestic prices of oil are below world oil prices. 


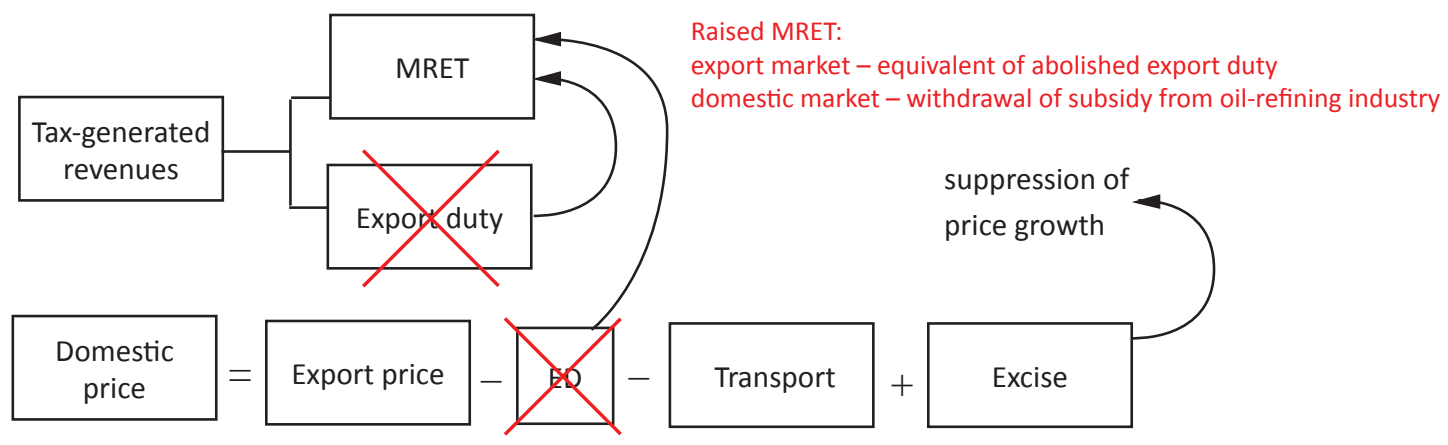

Fig. 2. An illustration of the tax maneuver

of the subsidy being transferred is absorbed by the domestic oil-refining sector $^{1}$, which produces negative value added in terms of world prices (Fig. 1), while end consumers get none of that subsidy. The production of negative value added means that each tonne of oil that could have been sold for export at a world price, and which is processed instead by Russian oil refineries, would have yielded an entire basket of petroleum products and saved approximately $25 \%$ of the associated expenses.

The political and economic paradox that becomes visible in the course of implementing the tax maneuver in actual practice is that it 'does not create incentives for increasing the oil extraction volume' ${ }^{2}$. Indeed, the idea behind the tax maneuver was ${ }^{3}$ that for each exported tonne of crude oil, the amount of abolished export duty should be replaced by that of MRET, while MRET should generate additional profit on each (now more expensive) tonne of crude oil in the domestic market. Such a maneuver makes it possible to release an additional budget resource that was previously transferred to Russia's oil-refining industry, and that now can be used for reducing the excises or for targeted subsidizing some socially important or energy-intensive projects (supplies to the northern regions, sowing campaigns, purchases for the army).

In the framework of such schemes, it is unprofitable for oil-extracting VICs (verticallly integrated companies) to increase their output. As a result, it is the 'bargaining' between incentives to increase output in the oil industry and the amount of the released budget resource that can lay the foundation for implementing the tax maneuver in Russia ${ }^{4}$.

1 Approximately $1.4 \%$ of GDP in current prices.

2 In 2011-2014, this was the main argument in favor of delaying the reform voiced at the expert meetings where the tax maneuver's parameters were discussed.

3 For the initial calculations, see Idrisov G. I., Sinelnikov-Murylev S. G. Modernization or Conservation: the Role of Export Duties on Oil and Oil Products. Economic Policy, 2012, No.3, pp. 5-19.

4 One example of such bargaining is the suspension, in the budget for 2016, of the planned reduction of export duty envisaged by the 2014 tax maneuver. The motive behind that decision is the desire to prevent a reduction in the amount of tax-generated revenues under the new terms of trade. For further details, see Bobylev Yu, Idrisov G., Kaukin A., Rasenko O. Oil, budget and tax maneuver. Online Monitoring of Russia's Economic Outlook, No.15 (November 2015), pp. 11-14. It should be noted that the increase of the tax burden was rather painless for the oil companies. This happened because the new level of oil prices was acceptable for the producers as, firstly, their costs are, for most part, denominated in rubles, and secondly, the plunge of oil prices translates mostly into reduced government revenue, and not into reduced incomes of oil producers. For more details, see G. Idrisov, A. Kaukin, O. Morgunova, M. Turuntseva. The two poles of Russian industry. Online Monitoring of Russia's Economic Outlook, No.12 (September) 2015, pp. 19-22. 
CURRENT TAX CONDITIONS

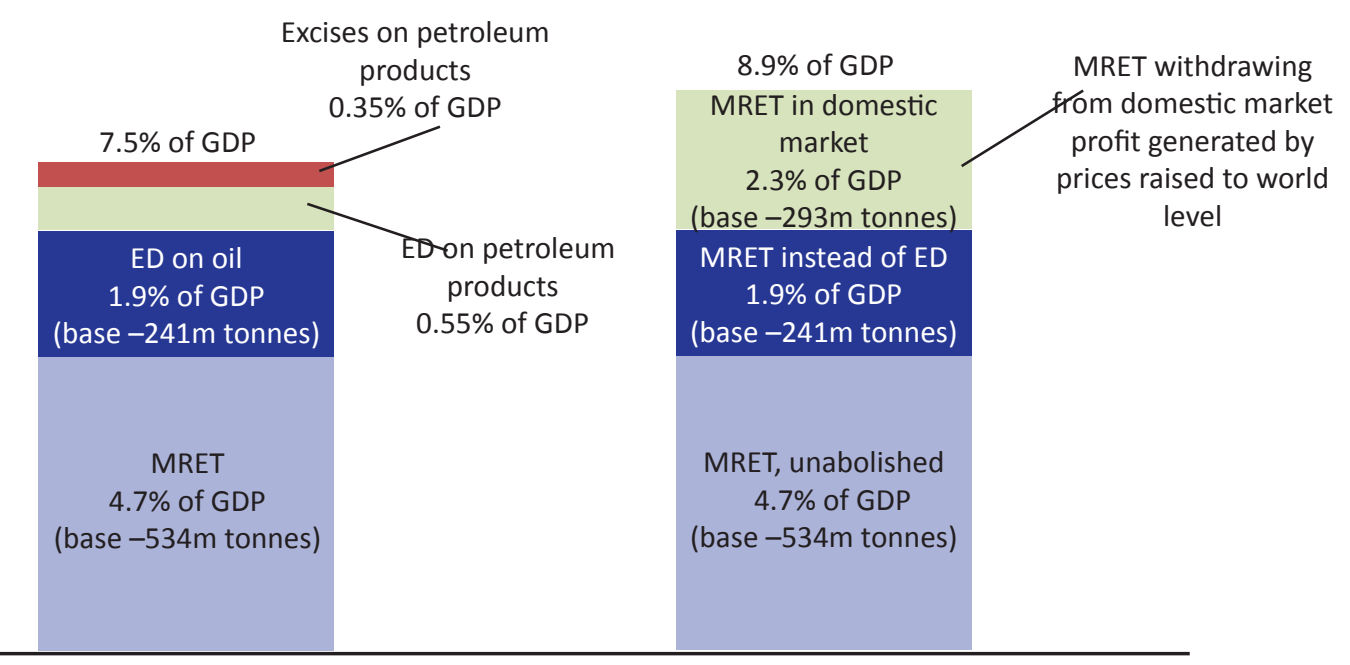

Sources: Rosstat; FTS; own calculations.

Fig. 3. Tax revenues generated by different tax schemes in the oil-extracting and oil-refining sectors, in 2015 prices; scenario-based Rb-to-USD exchange rate $=60$, scenario-based price of oil $-\$ 50$ per barrel

In fact, the actually adopted legislative measures represent an intermediate version, where the export duty is to be reduced slowly, and not to zero, MRET is to be raised by an amount that does not compensate in full for the loss resulting from the reduced duty, so that oil companies could derive profit from the tax maneuver, and would want to increase their output. The budgetrelated aspects have been sacrificed - the tax maneuver, in its current configuration, is almost neutral from the point of view of budgetary effects.

By way of illustrating what can happen next, we did three variants of model calculations ${ }^{1}$. The first one envisages the implementation of the tax maneuver in accordance with the parameters established by the RF Tax Code for 2017; the second one likewise envisages its implementation in accordance with the parameters established by the RF Tax Code for 2017, with the exception of the rate of export duty on oil, which is to be frozen at its current level (these alterations were temporarily initiated by the government in late 2015); the third one envisages full implementation of the big tax maneuver in accordance with the IEP's recommendations: the reduction to zero of the rates of export duties and the excise on gasoline, and the raise of the basic rate of MRET. In this connection, we studied three variants of the terms of trade (price of oil in combination with the foreign exchange rate, see Table 1).

No doubt that the implementation of the variant suggested by us - a tax maneuver that would be neutral in terms of tax load and positive in terms of budget - will be complicated politically. However, in view of the current low prices of oil and the budgetary effect of 1.4 p.p. of GDP, it will generate an additional benefit - by reducing the excises, we can fully suppress the growth

1 For more details on the methodology for calculating the parameters of Russian petroleum products and oil, see Idrisov G.I., Sinelnikov-Murylev S.G. Oil Export Duty: Cancel or Preserve. Neft Rossii, No 12, December, 72-77; Idrisov G.I., Sinelnikov-Murylev S.G. Modernization or Conservation: the Role of Export Duties on Oil and Oil Products. Economic Policy, 2012, No.3, pp. 5-19. 
of prices for petroleum products ${ }^{1}$. Meanwhile, from the point of view of economics, the suggested alternatives are understandable, and their interpretation is transparent: one has to make a choice between withdrawing from the oil sector the subsidy generated by cheap oil and generating a positive value added, or leaving that subsidy intact in one or other way, and transferring the mineral resource rent to VICs and hoping for output growth that can translate in growth of real GDP.

Table 1

\section{THE CALCULATED EFFECTS OF THE TAX MANEUVER'S VARIOUS MODIFICATIONS UNDER DIFFERENT TERMS OF TRADE}

\begin{tabular}{|c|c|c|c|c|}
\hline & 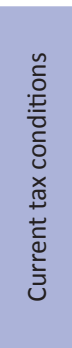 & 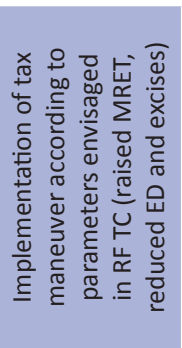 & 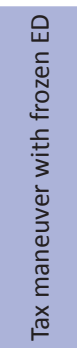 & 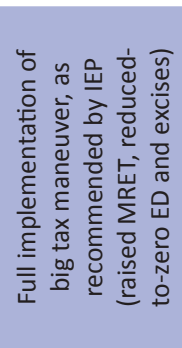 \\
\hline \multicolumn{5}{|c|}{ Rb-to-USD exchange rate $=60$, price of Urals $=\$ 50$ per barrel } \\
\hline \multicolumn{5}{|l|}{ Growth of gasoline prices, \% } \\
\hline retail, for individuals & & -1.80 & -5.95 & -7.48 \\
\hline wholesale, for industrial companies & & -2.49 & -6.78 & -9.38 \\
\hline \multicolumn{5}{|l|}{ Budget revenue, $\%$ of GDP } \\
\hline generated by MRET on oil & 4.70 & 5.04 & 5.04 & 8.92 \\
\hline generated by export duty on oil & 1.91 & 1.51 & 1.91 & 0.00 \\
\hline generated by export duty on petroleum products & 0.55 & 0.46 & 0.55 & 0.00 \\
\hline generated by excises on petroleum products & 0.36 & 0.28 & 0.28 & 0.00 \\
\hline Change in budget revenue volume, pp. of GDP & & -0.22 & 0.27 & 1.40 \\
\hline \multicolumn{5}{|c|}{ Rb-to-USD exchange rate $=70$, price of Urals $=\$ 40$ per barrel } \\
\hline \multicolumn{5}{|l|}{ Growth of gasoline prices, \% } \\
\hline retail, for individuals & & -2.65 & -5.95 & -8.95 \\
\hline wholesale, for industrial companies & & -3.37 & -6.78 & -10.91 \\
\hline \multicolumn{5}{|l|}{ Budget revenue, $\%$ of GDP } \\
\hline generated by MRET on oil & 3.92 & 4.20 & 4.20 & 7.43 \\
\hline generated by export duty on oil & 1.58 & 1.30 & 1.58 & 0.00 \\
\hline generated by export duty on petroleum products & 0.46 & 0.40 & 0.46 & 0.00 \\
\hline generated by excises on petroleum products & 0.36 & 0.28 & 0.28 & 0.00 \\
\hline Change in budget revenue volume, pp. of GDP & & -0.13 & 0.21 & 1.12 \\
\hline \multicolumn{5}{|c|}{ Rb-to-USD exchange rate $=80$, price of Urals $=\$ 30$ per barrel } \\
\hline \multicolumn{5}{|l|}{ Growth of gasoline prices, $\%$} \\
\hline retail, for individuals & & -3.94 & -5.95 & -11.26 \\
\hline wholesale, for industrial companies & & -4.70 & -6.78 & -13.31 \\
\hline \multicolumn{5}{|l|}{ Budget revenue, $\%$ of GDP } \\
\hline generated by MRET on oil & 2.69 & 2.88 & 2.88 & 5.10 \\
\hline generated by export duty on oil & 1.07 & 0.96 & 1.07 & 0.00 \\
\hline generated by export duty on petroleum products & 0.31 & 0.29 & 0.31 & 0.00 \\
\hline generated by excises on petroleum products & 0.36 & 0.28 & 0.28 & 0.00 \\
\hline Change in budget revenue volume, $\mathrm{pp}$. of GDP & & 0.00 & 0.12 & 0.68 \\
\hline
\end{tabular}

Sources: Rosstat; FTS; own calculations.

1 And our model calculations demonstrate that, if the excises are fully abolished, prices may even go down. 